\title{
SISTEM PERAMALAN PENJUALAN BARANG MENGGUNAKAN METODE FORECASTING EXPONENTIAL SMOOTHING DI WAROENG BINGKAI
}

\author{
Hari Irawan Azis ${ }^{1}$, Nurul Kamilah ${ }^{2}$, Dewi Primasari ${ }^{3}$ \\ Program Studi Teknik Informatika ${ }^{123}$ \\ Universitas Ibn Khaldun Bogor \\ Jl. Sholeh Iskandar Bogor \\ hari.azis4481@gmail.com ${ }^{1}$, mila.ipb@gmail.com ${ }^{2}$, dewi.primasari@ ft.uika-bogor.ac.id ${ }^{3}$
}

\begin{abstract}
Abstrak
Waroeng Bingkai merupakan perusahaan yang bergerak di bidang perdagangan dan jasa, yang berhubungan dengan penjualan beraneka ragam jenis bingkai. Semua transaksi pada proses bisnis di Waroeng Bingkai, dilakukan dengan cara manual yaitu mencatat pada selembar kertas, tentu hal tersebut sangat beresiko, karena mudahnya media tersebut hilang dan rusak yang akan berakibat pada hilangnya data dan tidak akuratnya transaksi. Ketika pengadaan stok, pemilik menentukan jumlah pengadaan berdasarkan observasi pada gudang dengan melihat stok yang akan habis, dengan cara tersebut terkadang penjualan bingkai tidak sesuai dengan yang diharapkan karena kelirunya prediksi pengadaan barang. Sistem informasi ini dirancang dengan metode waterfall sehingga menghasilkan, rancangan sistem yang akan dikembangkan, diagram konteks, diagram usecase. Sistem informasi ini dapat digunakan oleh pemlik, admin gudang, dan admin penjualan, yang bertujuan untuk mengelola stok barang, data barang, keluar masuk barang, dan mencetak laporan. Pada pengadaan barang digunakan metode forecasting exponential smoothing dengan nilai konstanta $\alpha$ (alfa) $=0,5$, dengan melihat nilai kesalahan peramalan terkecil menggunakan 3 metode yaitu MAD $=15$, MSE $=485$, MAPE $=12,54 \%$. Ramalan penjualan bulan agustus untuk bingkai ukuran A4 adalah 135 pcs.
\end{abstract}

Kata kunci : Sistem Informasi, Forecasting, Exponential Smoothing

\section{Abstract \\ Waroeng Bingkai is a company engaged in trading and service, which deals with the sale of}

various types of frames. All transactions in the business process at Waroeng Bingkai are done manually, recording on a piece of paper, of course this is very risky, because it is easy for the media to be lost and damaged which will result in data loss and inaccurate transactions. When procuring stock, the owner determines the amount of procurement based on observations on the warehouse by looking at the stock that will run out. This information system is designed with the waterfall method so as to produce, system design to be developed, context diagrams, usecase diagrams. This information system can be used by owner, warehouse admin, and sales admin, which aims to manage inventory, goods data, goods in and out, and print reports. For procurement of goods, forecasting exponential smoothing method is used to predict the number of sales in the following month. From the results of data analysis, in this case the suitable forecasting is forcasting exponential smoothing with a constant value of $\alpha$ (alpha) $=0,5$, by looking at the smallest focecast error value using 3 methods, namely $M A D=15, M S E=485, M A P E=$ 12,54\%. August sales forecast for A4 size frame is 135 pcs.

Keywords : Information System, Forecasting, Exponential Smoothing

\section{PENDAHULUAN}

Perusahaan perdagangan merupakan perusahaan yang bergerak dengan bisnis utama membeli barang dari pemasok, lalu menjual kembali kepada konsumen tanpa mengubah barang tersebut (Sentono, 2005). Dalam proses bisnis sangat penting untuk selalu mengelola persediaan, agar pesanan konsumen selalu tersedia.

Hari Irawan Azis, Nurul Kamilah, Dewi Primasari

Jurnal Ilmiah Teknologi Informasi Terapan

Volume 7, No 1, 15 Desember 2020 
Waroeng Bingkai merupakan perusahaan yang bergerak dibidang perdagangan dan jasa, yang berhubungan dengan penjualan beraneka ragam jenis bingkai. Penjualan barang pada Waroeng Bingkai sekitar 3000 pcs bingkai dalam 1 bulan. Minimnya pasokan atau persediaan stok barang menjadi kendala disaat permintaan pesanan barang meningkat. Hal ini menyebabkan pelayanan pesanan menjadi lambat. Banyaknya pembeli mengeluh karena pesanannya terlalu lama. Begitu juga dengan stok barang, pemilik mengalami kesulitan dalam memprediksi penjualan apa saja yang akan terjadi diperiode kedepan yang berakibat kesulitannya untuk menentukan berapa banyak bahan yang harus dibeli dan apa saja yang harus dibeli. Semua hal tersebut tak lepas dari kesalahan prediksi pemilik untuk menentukan produk apa saja yang akan terjual dimasa depan.

Dengan permasalahan diatas, peranan peramalan penjualan barang dimasa depan sangat dibutuhkan untuk memberikan informasi kepada pemilik sebagai acuan menentukan pembelian barang apa saja yang akan dibeli untuk penjualan diperiode yang akan datang, guna meningkatkan kegiatan penjualan di Waroeng Bingkai. Oleh karena penelitian ini bertujuan untuk membangun sistem peramalan penjualan barang dengan metode forecasting exponential smoothing di Waroeng Bingkai, untuk menunjang hal-hal tersebut.

\section{TINJAUAN PUSTAKA}

\section{II.1 Gambaran Umum Instansi}

Waroeng Bingkai merupakan salah satu anak usaha dari De'melo Production. De'melo Production sendiri mempunyai dua anak usaha yaitu Waroeng Bingkai dan De'melo Photographi. Semua anak usaha bertempat pada satu kantor yang beralamat pada Jl. M.Sanun No. 16 Harapan Jaya, Kecamatan Cibinong, Kabupaten Bogor.

De'melo fotografi masuk pada bidang usaha jasa yang melayani fotografi, photo wedding, dan video wedding sedangkan Waroeng Bingkai merupakan sebuah toko yang melayani penjualan bingkai, album foto, standing frame, souvenir wedding, surat undangan, cetak foto, sewa standing frame, dekorasi frame, lebih mengarah pada fotografi support. Sumber penghasilan De'melo Production meliputi jasa, toko retail dan toko online yang pada sebagian besar marketplace yang ada diindonesia.

\section{II.2 Sistem Informasi}

Sistem informasi dapat didefinisikan sebagai integrasi antara orang, data, alat dan prosedur yang bekerja sama dalam mencapai suatu tujuan. Jadi didalam sistem informasi terdapat elemen, orang, alat dan prosedur atau cara (Nugroho, 2010).

Sistem informasi adalah suatu sistem didalam suatu organisasi yang mempertemukan kebutuhan pengelolaan transaksi harian yang mendukung fungsi operasi organisasi yang bersifat manajerial dengan kegiatan stategis dari suatu organisasi untuk dapat menyediakan kepada pihak luar tertentu dengan laporan-laporan yang diperlukan (Sutabri, 2012).

\section{II.3 Ramalan (Forecasting)}

Menurut (Jay Heizer dan Barry Render, 2015) mengatakan bahwa peramalan adalah seni atau ilmu untuk memperkirakan kejadian dimasa depan. Hal ini dapat dilakukan dengan melibatkan pengambilan data historis dan memproyeksikannya ke masa mendatang dengan suatu model sistematis. Hal ini dapat dilakukan dengan menggunakan kombinasi model matematis yang disesuaikan dengan pertimbangan dari seorang manajer.

Berdasarkan waktu, peramalan dapat dibagi menjadi tiga jenis, yaitu:

1. Peramalan jangka pendek: Peramalan ini memiliki rentang waktu sampai dengan 1 tahun, tetapi umumnya kurang dari 3 bulan. Digunakan untuk perencanaan pembelian, penjadwalan pekerjaan, level angkatan kerja, penugasan pekerjaan, dan level produksi.

2. Peramalan jangka menengah: Kisaran menengah, atau intermediate, peramalan umumnya rentang waktu 3 bulan hingga 3 tahun. Berguna dalam perencanaan penjualan, perencanaan produksi dan penganggaran, penganggaran uang kas, dan analisis variasi rencana operasional.

3. Peramalan kisaran panjang: Umumnya 3 tahun lebih dalam rentang waktunya, peramalan jangka panjang digunakan dalam perencanaan untuk produk baru, pengeluaran modal, lokasi tempat fasilitas atau perluasan, dan penelitian serta pengembangan.

Pada kebanyakan organisasi menggunakan 3 tipe peramalan utama dalam merencanakan operasional untuk masa mendatang.

Hari Irawan Azis, Nurul Kamilah, Dewi Primasari

Jurnal Ilmiah Teknologi Informasi Terapan

Volume 7, No 1, 15 Desember 2020 
1. Peramalan ekonomi, menangani siklus bisnis dengan memprediksi tingkat inflasi, uang yang beredar, mulai pembangunan perumahan.

2. Peramalan teknologi, berkaitan dengan tingkat pengembangan teknologi, dimana dapat menghasilkan terciptanya produk baru yang lebih menarik, yang memerlukan pabrik dan perlengkapan baru.

3. Peramalan permintaan, adalah proyeksi atas permintaan untuk produk atau jasa dari perusahaan. Peramalan mendorong keputusan sehingga para manajer memerlukan informasi dengan segera dan akurat mengenai permintaan yang sesungguhnya. Mereka memerlukan peramalan yang didorong oleh permintaan, dimana fokus perhatian pada pengidentifikasi dan pelacakan keinginan konsumen dengan sangat cepat.

Jika artikel anda memuat gambar dan rumus, agar diperhatikan contoh pemuatan gambar seperti pada gambar 1. [setiap gambar harus diacu pada tulisan, misalnya "seperti terlihat pada gambar 1", Jika menyertakan gambar, usahakan gambar dibuat cukup terang, dan hindari gambar dari screenshoot yang kurang jelas. Jika gambar diambil dari referensi atau literature, agar disertakan acuan yang relevan pada gambar tersebut.

\section{II.4 Exponential Smoothing}

Menurut (Jay Heizer dan Barry Render, 2015), penghalusan exponential smoothing adalah sebuah pergerakan rata-rata (moving average) bobot teknik peramalan, dimana point-point data ditimbang oleh sebuah fungsi eksponensial. Formulasi penghalus eksponensial dasar dapat diperlihatkan sebagai berikut.

$$
\begin{aligned}
& F t=F t-1+\alpha(A t-1-F t-1) \\
F_{t} & =\text { peramalan yang baru } \\
F_{t-1} & =\text { peramalan periode sebelumnya } \\
\alpha & =\text { penghalus (atau bobot) konstan }(0 \leq= \\
& \alpha<=1) \\
A_{t-1} & =\text { permintaan aktual periode sebelumnya }
\end{aligned}
$$

\section{II.5 Metode Ketepatan Ramalan}

Keseluruhan keakuratan beberapa model peramalan moving avarage, exponential smoothing, atau lainnya dapat ditentukan dengan membandingkan nilai yang diramal dengan nilai yang aktual atau yang diamati. Kesalahan peramalan atau deviasi didefinisikan sebagai berikut (Jay Heizer dan Barry Render, 2015).

$$
\text { Kesalahan Ramalan }=A_{t}-F_{t}
$$

$$
\begin{aligned}
& A_{t} \quad=\text { peramalan yang baru } \\
& F_{t} \quad=\text { peramalan periode sebelumnya }
\end{aligned}
$$

Tiga ukuran yang paling terkenal adalah deviasi rata-rata yang absolut (mean absolute deviation MAD), kesalahan yang dikuadratkan (mean squared error - MSE), dan kesalahan rata-rata yang absolut (mean absolute percent error-MAPE).

\section{II.5.1 Mead absolute deviation (MAD)}

Mean absolute deviation adalah deviasi rata-rata yang absolut ukuran pertama atas keseluruhan adalah kesalahan peramalan untuk model. Nilai ini dihitung dengan jumlah nilai absolut kesalahan peramalan individual (deviasi) dan membaginya dengan jumlah periode data $(n)$. berikut rumus MAD.

$$
\mathrm{MAD}=\frac{\sum \mid \text { Aktual-Peramalan } \mid}{n}
$$

\section{II.5.2 Mean square error (MSE)}

Mean square error adalah perbedaan yang dikuadratkan diantara nilai yang diramalkan dengan yang diamati. Rumusnya adalah sebagai berikut.

$$
\text { MSE }=\frac{\sum \mid \text { Aktual-Peramalan }\left.\right|^{2}}{n}
$$

\section{II.5.3 Mean absolute percentage error (MAPE)}

Mean absolute percentage error adalah kesalahan rata-rata yang absolut yang dicerminkan pada persentase. Rumusnya adalah sebagai berikut.

$$
\text { MAPE }=\frac{\sum\left(\frac{\mid \text { Aktual-Peramalan } \mid}{\text { Aktual }}\right) * 100}{n}
$$

Hari Irawan Azis, Nurul Kamilah, Dewi Primasari

Jurnal Ilmiah Teknologi Informasi Terapan

Volume 7, No 1, 15 Desember 2020 


\section{II.6 Metode Pengembangan Sistem}

Menurut (Sommerville, 2007), model publikasi pertama dari proses pengembangan perangkat lunak diturunkan dari proses rekayasa sistem yang lebih umum oleh Royce pada tahun 1970. Ini diilustrasikan pada gambar 1, karena cascade dari satu fase ke fase lain, model ini dikenal sebagai waterfall atau software life cycle. Tahapan utama dari peta model ke dalam kegiatan pembangunan mendasar sebagai berikut.

1. Analisa dan definisi persyaratan layanan, kendala, dan tujuan sistem, didirikan melalui konsultasi dengan pengguna sistem, kemudian didefinisikan secara rinci dan berfungsi sebagai spesifikasi sistem.

2. Desain sistem dan perangkat lunak. Proses desain sistem mempertisi persyaratan untuk sistem perangkat keras atau perangkat lunak. Itu membangun keseluruhan arsitektur sistem. Desain perangkat lunak melibatkan pengidentifikasian dan penggabaran yang mendasar abstraksi sistem perangkat lunak dan hubungannya.

3. Implementasi dan pengujian unit. Selama tahap ini, desain perangkat lunak direalisasikan sebagai seperangkat program atau unit program. Pengujian unit melibatkan verifikasi bahwa setiap unit memenuhi spesifikasinya.

4. Integrasi dan pengujian sistem. Unit atau unit program individu terintegrasi dan diuji sebagai sistem yang lengkap untuk memastikan bahwa persyaratan perangkat lunak telah terpenuhi. Setelah pengujian sistem perangkat lunak dikirim ke pelanggan.

5. Pengoperasian dan pemeliharaan. Biasanya (walaupun tidak harus) ini adalah fase siklus hidup terpanjang. Sistem diinstal dan digunakan secara praktis. Maintenance melibatkan koreksi kesalahan yang tidak ditemukan pada tahap awal siklus hidup, meningkatkan implementasi unit sistem dan meningkatkan layanan sistem sebagai persyaratan baru yang ditemukan.

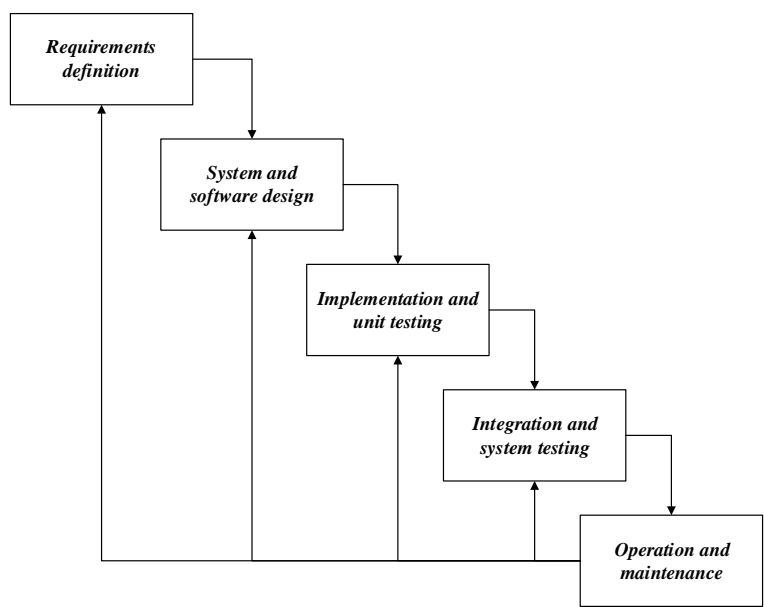

Gambar 1. Waterfall model (Sommerville, Software Engineering 2007)

\section{METODE PENELITIAN}

\section{III.1 Tempat dan Waktu}

Pelaksanaan penelitian dilaksanakan pada tanggal 4 Februari 2019 sampai dengan 28 Juni 2019. Dengan tempat penelitian ditoko Waroeng Bingkai yang beralamat di Jl. M.Sanun No. 16 Harapan Jaya, Kecamatan Cibinong, Kabupaten Bogor.

\section{III.2 Bahan dan Alat}

Bahan penelitian terdiri dari.

1. Hasil rekaman wawancara dari pemilik Waroeng Bingkai

2. Dokumen transaksi penjualan dan pembelian

3. Dokumen data barang

4. Dokumentasi foto

Alat yang digunakan untuk penelitian terdiri dari perangkat keras (Hardware) dan perangkat lunak (Software), yang dispesifikasikan pada tabel berikut.

Tabel 1. Spesifikasi Perangkat Keras

\begin{tabular}{|c|c|c|}
\hline No & Jenis & Spesifikasi \\
\hline 1 & Notebook & Acer Aspire 4739 \\
\hline 2 & Prosessor & Intel Core i3-370M \\
\hline 3 & Ram & 4 GB DDR3 \\
\hline
\end{tabular}

Hari Irawan Azis, Nurul Kamilah, Dewi Primasari

Jurnal Ilmiah Teknologi Informasi Terapan

Volume 7, No 1, 15 Desember 2020 


\begin{tabular}{|c|c|c|}
\hline 4 & Hdd & 320 GB \\
\hline 5 & Modem & Teatering Xiaomi MI4I \\
\hline 6 & Printer & HP Deskjet 2135 \\
\hline
\end{tabular}

Tabel 2. Spesifikasi Perangkat Lunak

\begin{tabular}{|c|c|c|}
\hline No & Jenis & Spesifikasi \\
\hline 1 & Sistem Operasi & Windows 10 \\
\hline 2 & Browser & Google Chrome \\
\hline 3 & Text Prosessing & Ms Word 2013 \\
\hline 4 & Tools UML & Visio 2013 \\
\hline
\end{tabular}

\section{III.3 Metode Pengembangan Sistem}

Pada metode pengembangan sistem informasi, yang digunakan mengacu pada konsep pengembangan sistem waterfall. Dengan model pengembangan sistem waterfall dimana setiap fase harus dilewati sesuai dengan urutan fase awal hingga fase akhir. Berikut urutan fase dan penjelasannya.

1. Fase analisis dan definisi persyaratan layanan, merupakan fase untuk menetukan jadwal dan tempat janji temu dengan pemilik, wawancara observasi lapangan, identifikasi masalah, analisa kebutuhan fungsional, analisa kebutuhan non fungsional, dan analisa data.

2. Fase desain sistem dan perangkat lunak, yaitu proses desain sistem yang menganalisa proses bisnis yang sedang berjalan dan proses bisnis yang akan dikembangkan, serta menggambarkan sebuah sistem informasi yang akan dikembangkan dalam bentuk pemodelan UML.

3. Fase implementasi, yaitu fase yang memgimplementasikan atau menterjemahkan suatu desain sistem atau gambaran sebuah sistem yang berbentuk pemodelan UML ke dalam bahasa mesin yaitu bahasa pemrograman berbasis web.

4. Fase integrasi dan pengujian sistem, merupakan tahap pengujian dari sebuah model sistem yang telah diterjemahkan ke dalam bahasa mesin. Pada fase ini sistem akan diuji kemampuan dan efektifitasnya sehingga dapat ditangkap kekurangan dan kelemahan yang akan menjadi perbaikan sebelum masuk pada fase berikutnya, fase testing akan menggunakan metode black box.

5. Fase pengoperasian dan pemeliharaan, merupakan fase setelah sistem diinstal dan digunakan. Penelitian ini tidak sampai fase ini.

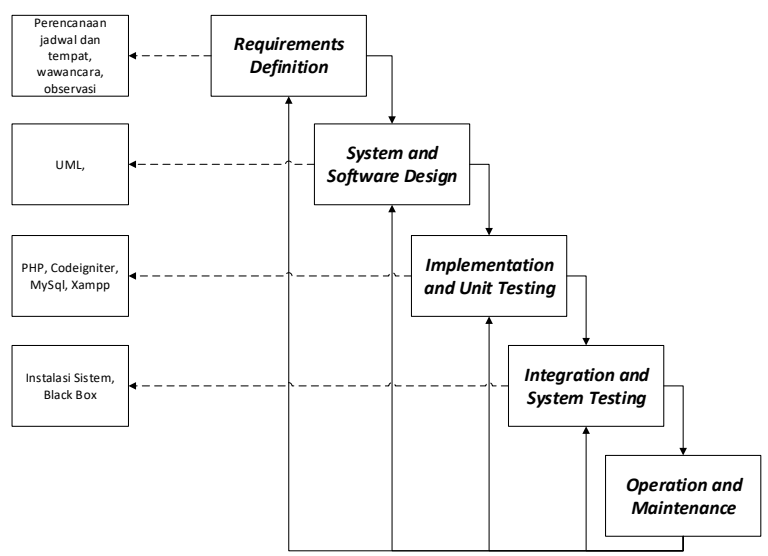

Gambar 2. Metode Pengembangan Sistem

\section{HASIL DAN PEMBAHASAN}

\section{IV.1 Analisa Data Penelitian}

Pada penelitian ini, perhitungan peramalan menggunakan data transaksi penjualan bingkai ukuran A4 pada waroeng bingkai selama 7 bulan terakhir, yaitu dari bulan januari 2019 sampai dengan bulan juli 2019 sebagai berikut.

Tabel 3. Data Penjualan Bingkai Ukuran A4

\begin{tabular}{|r|c|c|}
\multicolumn{1}{|l|}{ Bulan } & Aktual & Satuan \\
\hline Januari 2019 & 153 & Pcs \\
\hline Februari 2019 & 120 & Pcs \\
\hline Maret 2019 & 136 & Pcs \\
\hline April 2019 & 140 & Pcs \\
\hline Mei 2019 & 101 & Pcs \\
\hline Juni 2019 & 120 & Pcs \\
\hline Juli 2019 & 150 & Pcs \\
\hline
\end{tabular}

Hari Irawan Azis, Nurul Kamilah, Dewi Primasari Jurnal Ilmiah Teknologi Informasi Terapan

Volume 7, No 1, 15 Desember 2020 
Data Penjualan Bingkai Ukuran A4

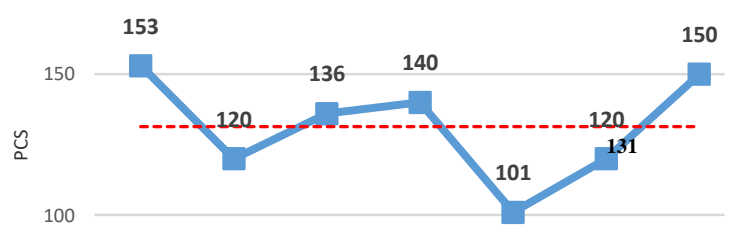

Jan-19 Feb-19 Mar-19 Apr-19 May-19 Jun-19 Jul-19

\section{Gambar 3. Grafik Penjualan Bingkai Ukuran A4}

Dari data tersebut menunjukan bahwa, penjualan bingkai ukuran A4 mempunyai kecenderungan (trend) mendatar dengan jumlah penjualan rata-rata berada pada 131 pcs dalam rentang waktu januari 2019 s/d juli 2019.

\section{IV.2 Perhitungan Peramalan Metode Exponential Smoothing}

Peramalan yang diharapkan adalah peramalan setiap bulan. Pada perhitungan peramalan ini konstanta yang akan digunakan adalah pada jangkauan $0 \leq=\alpha<=1$, yaitu $\alpha=0, \alpha=0,1, \alpha=0,2$, $\alpha=0,3, \alpha=0,4, \alpha=0,5, \alpha=0,6, \alpha=0,7, \alpha=0,8, \alpha=$ $0,9, \alpha=1$. Berikut perhitungannya.

$$
F t=F t-1+\alpha(A t-1-F t-1)
$$

$$
\begin{array}{ll}
F_{t} & =\text { peramalan yang baru } \\
F_{t-1} & =\text { peramalan periode sebelumnya } \\
\alpha & =\text { penghalus (atau bobot) konstan }(0 \leq= \\
& \alpha<=1)
\end{array}
$$

\begin{tabular}{|c|c|c|c|c|c|c|}
\hline \multirow{2}{*}{ Produk } & \multirow{2}{*}{ Bulan } & \multirow{2}{*}{ Aktual/At } & \multicolumn{4}{|c|}{ Forecase exponential smoothing $/ \mathrm{F}_{\mathrm{t}}$} \\
\hline & & & $\alpha=0$ & $\alpha=\mathbf{0 , 1}$ & $\alpha=0,2$ & $\alpha=0,3$ \\
\hline \multirow{7}{*}{ Bingkai Ukuran A4 } & Jan-19 & 153 & 153 & 153 & 153 & 153 \\
\hline & Feb-19 & 120 & 153 & 153 & 153 & 153 \\
\hline & $\operatorname{Mar}-19$ & 136 & 153 & 150 & 146 & 143 \\
\hline & Apr-19 & 140 & 153 & 148 & 144 & 141 \\
\hline & May-19 & 101 & 153 & 147 & 143 & 141 \\
\hline & Jun-19 & 120 & 153 & 143 & 135 & 129 \\
\hline & Jul-19 & 150 & 153 & 141 & 132 & 126 \\
\hline & Jumlah : & 920 & 1071 & 1035 & 1007 & 986 \\
\hline \multirow{2}{*}{ Produk } & \multirow{2}{*}{ Bulan } & \multirow{2}{*}{ Aktual/A $\mathbf{A}_{\mathbf{t}}$} & \multicolumn{4}{|c|}{ Forecase exponential smoothing $/ \mathrm{F}_{\mathrm{t}}$} \\
\hline & & & $\alpha=0,4$ & $\alpha=0,5$ & $\alpha=0,6$ & $\alpha=0,7$ \\
\hline \multirow{8}{*}{ Bingkai Ukuran A4 } & Jan-19 & 153 & 153 & 153 & 153 & 153 \\
\hline & Feb-19 & 120 & 153 & 153 & 153 & 153 \\
\hline & Mar-19 & 136 & 140 & 137 & 133 & 130 \\
\hline & Apr-19 & 140 & 138 & 136 & 135 & 134 \\
\hline & May-19 & 101 & 139 & 138 & 138 & 138 \\
\hline & Jun-19 & 120 & 124 & 120 & 116 & 112 \\
\hline & Jul-19 & 150 & 122 & 120 & 118 & 118 \\
\hline & Jumlah : & 920 & 969 & 956 & 946 & 938 \\
\hline
\end{tabular}

$A_{t-1} \quad=$ permintaan aktual periode sebelumnya

Tabel 4. Hasil Perhitungan Exponential Smoothing Range $0 \leq=\alpha<=1$

Hari Irawan Azis, Nurul Kamilah, Dewi Primasari Jurnal Ilmiah Teknologi Informasi Terapan

Volume 7, No 1, 15 Desember 2020 


\begin{tabular}{|c|c|c|c|c|c|}
\hline \multirow{2}{*}{ Produk } & \multirow{2}{*}{ Bulan } & \multirow{2}{*}{ Aktual/At } & \multicolumn{3}{|c|}{ Forecase exponential smoothing $/ \mathrm{F}_{\mathrm{t}}$} \\
\hline & & & $\alpha=0,8$ & $\alpha=0,9$ & $\alpha=1$ \\
\hline \multirow{7}{*}{ Bingkai Ukuran A4 } & Jan-19 & 153 & 153 & 153 & 153 \\
\hline & Feb-19 & 120 & 153 & 153 & 153 \\
\hline & Mar-19 & 136 & 127 & 123 & 120 \\
\hline & Apr-19 & 140 & 134 & 135 & 136 \\
\hline & May-19 & 101 & 139 & 139 & 140 \\
\hline & Jun-19 & 120 & 109 & 105 & 101 \\
\hline & Jul-19 & 150 & 118 & 118 & 120 \\
\hline & Jumlah : & 920 & 932 & 927 & 923 \\
\hline
\end{tabular}

Penjelasan tabel diatas adalah pada kolom forecasting exponential smoothing, merupakan hasil perhitungan ramalan dari periode januari $2019 \mathrm{~s} / \mathrm{d}$ juli 2019 dengan menggunakan konstanta pada rentang 0 $\leq=\alpha<=1$, yaitu $\alpha=0, \alpha=0,1, \alpha=0,2, \alpha=0,3, \alpha=$ $0,4, \alpha=0,5, \alpha=0,6, \alpha=0,7, \alpha=0,8, \alpha=0,9, \alpha=1$.

\section{IV.3 Mencari Konstanta Terbaik Dengan Perhitungan Nilai Kesalahan Ramalan}

Setelah mendapatkan hasil perhitungan exponential smoothing, tahap berikutnya adalah menghitung nilai kesalahan dengan 3 metode yaitu Mead Absolute Deviation (MAD), Mean Square Error (MSE), Mean Absolute Percentage Error (MAPE). Perhitungan ini bertujuan untuk mencari nilai kesalahan peramalan terkecil dan menentukan konstanta yang akan dipilih. Berikut penjelasannya.

$$
\mathrm{MAD}=\frac{\sum \mid \text { Aktual-Peramalan } \mid}{n}
$$

$$
\mathrm{MSE}=\frac{\sum \mid \text { Aktual-Peramalan } \mid}{n}
$$

$$
\text { MAPE }=\frac{\sum\left(\frac{\mid \text { Aktual-Peramalan } \mid}{\text { Aktual }}\right) * 100}{n}
$$

Tabel 5. Perhitungan Nilai Kesalahan

\begin{tabular}{|c|r|r|r|r|}
\hline \multirow{2}{*}{ Metode } & \multicolumn{4}{|c|}{ Konstanta } \\
\cline { 2 - 5 } & $\boldsymbol{\alpha}=\mathbf{0}$ & $\boldsymbol{\alpha}=\mathbf{0 , 1}$ & $\boldsymbol{\alpha}=\mathbf{0 , 2}$ & $\boldsymbol{\alpha}=\mathbf{0 , 3}$ \\
\hline Nilai Kesalahan MAD & 21,57 & 19,12 & 17,60 & 16,20 \\
\hline Nilai Kesalahan MSE & 764,14 & 588,44 & 509,61 & 480,14 \\
\hline Nilai Kesalahan MAPE & 18,61 & 16,41 & 14,97 & 13,70 \\
\hline Metode & & \multicolumn{2}{|c|}{ Konstanta } & \multicolumn{1}{|c|}{} \\
\hline \multirow{2}{*}{ Nilai Kesalahan MAD } & $\boldsymbol{\alpha}=\mathbf{0 , 4}$ & $\boldsymbol{\alpha}=\mathbf{0 , 5}$ & $\boldsymbol{\alpha}=\mathbf{0 , 6}$ & 17,48 \\
\hline Nilai Kesalahan MSE & 15,43 & 15,00 & 16,25 & 522,20 \\
\hline Nilai Kesalahan MAPE & 475,90 & 484,99 & 501,49 & 14,45 \\
\hline
\end{tabular}

Hari Irawan Azis, Nurul Kamilah, Dewi Primasari

Jurnal Ilmiah Teknologi Informasi Terapan

Volume 7, No 1, 15 Desember 2020 


\begin{tabular}{|c|r|r|r|}
\hline \multirow{2}{*}{ Metode } & \multicolumn{3}{|c|}{ Konstanta } \\
\cline { 2 - 4 } & $\boldsymbol{\alpha}=\mathbf{0 , 8}$ & $\boldsymbol{\alpha}=\mathbf{0 , 9}$ & $\boldsymbol{\alpha}=\mathbf{1}$ \\
\hline Nilai Kesalahan MAD & 18,55 & 19,44 & 20,14 \\
\hline Nilai Kesalahan MSE & 545,12 & 568,72 & 591,86 \\
\hline Nilai Kesalahan MAPE & 15,30 & 16,05 & 16,65 \\
\hline
\end{tabular}

Dari rangkuman data hasil perhitungan nilai kesalahan forecasting exponential smoothing. Bobot atau konstanta pada jangkauan $0 \leq=\alpha<=1$ dengan perhitungan nilai kesalahan terkecil menggunakan metode MAD adalah konstanta $\alpha=0,5$ dengan nilai kesalahan yaitu $\mathrm{MAD}=15$. Perhitungan nilai kesalahan terkecil menggunakan metode MSE adalah $\alpha=0,4$ dengan nilai kesalahan MSE $=475,9$. Perhitungan nilai kesalahan terkecil menggunakan metode MAPE adalah $\alpha=0,5$ dengan nilai kesalahan $\mathrm{MAPE}=12,54 \%$.

Dengan data tersebut, dapat diambil kesimpulan bahwa penghalus/bobot yang terbaik pada rentang konstanta $0 \leq=\alpha<=1$ untuk forecasting exponential smoothing pada penelitian ini adalah konstanta $\alpha=$ 0,5 , karena mempunyai nilai kesalahan yang terkecil dari 2 metode perhitungan kesalahan peramalan yaitu $\mathrm{MAD}=15$ dan $\mathrm{MAPE}=475,9$.

Karena sudah ditetapkannya konstanta terbaik yaitu $\alpha=0,5$, maka dapat dihitung forecasting untuk bulan berikutnya. Penjelasannya sebagai berikut.

Tabel 6. Forecasting Exponential Smoothing Bulan Agustus 2019

\begin{tabular}{|c|c|c|c|}
\hline \multicolumn{4}{|c|}{ Forecast single exponential bulan agustus 2019} \\
\hline Produk & Bulan & Aktual & $\alpha=0,5$ \\
\hline \multirow{8}{*}{$\begin{array}{l}\text { Bingkai } \\
\text { Ukuran A4 }\end{array}$} & Jan-19 & 153 & 153 \\
\hline & Feb-19 & 120 & 153 \\
\hline & Mar-19 & 136 & 137 \\
\hline & Apr-19 & 140 & 136 \\
\hline & May-19 & 101 & 138 \\
\hline & Jun-19 & 120 & 120 \\
\hline & Jul-19 & 150 & 120 \\
\hline & Aug-19 & & 135 \\
\hline
\end{tabular}

Tabel diatas menunjukan bahwa, ramalan penjualan untuk bingkai ukuran A4 pada bulan agustus 2019 adalah 135 pcs.

\section{IV.4 Analisa Sistem Yang Akan Dikembangkan}

Berdasarkan analisis dan observasi proses bisnis yang sedang berjalan, maka untuk mendapat sistem informasi yang optimal dan dapat diterjemahkan ke dalam bahasa pemrograman, maka dirancang sistem yang akan dikembangkan pada setiap bisnis proses. Berikut penjelasan sistem yang akan dikembangkan.

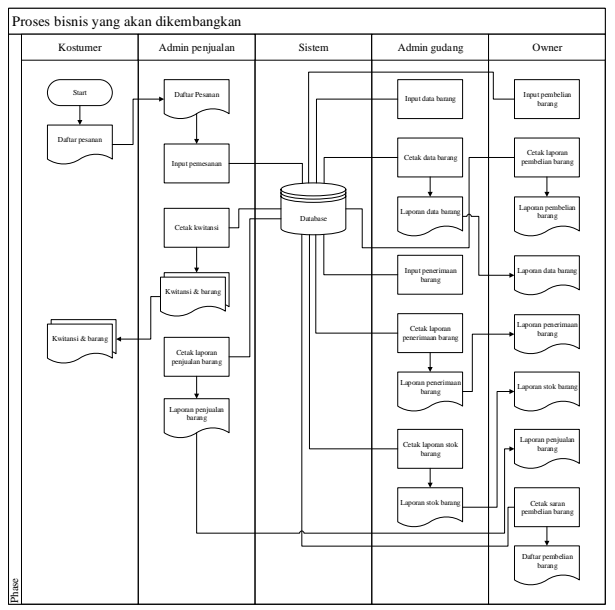

Gambar 3. Proses Bisnis Yang Akan Dikembangkan

\section{IV.5 Diagram Konteks}

Diagram konteks dibutuhkan untuk menggambarkan ruang lingkup suatu sistem secara menyeluruh akan bagaimana sistem yang baru dibangun dan juga untuk menemukan aktor yang terlibat dalam sistem yang akan dirancang. Berikut merupakan diagram kontek dari usulan perancangan sistem informasi inventori barang pada Waroeng Bingkai. 


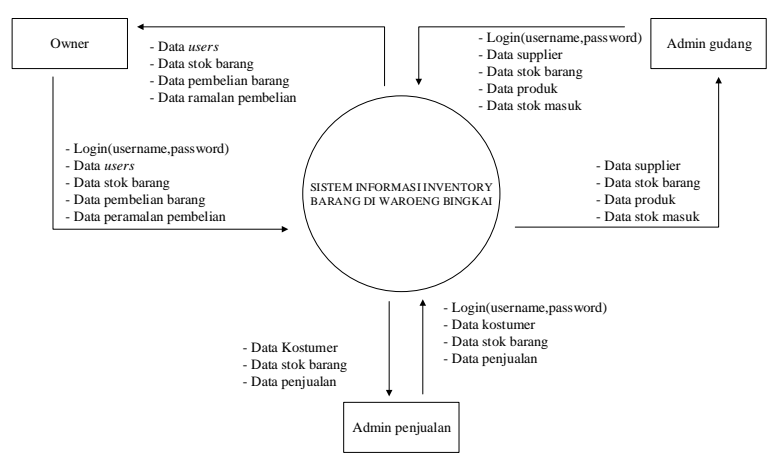

Gambar 5. Diagram Konteks

\section{IV.6 Identifikasi Pelaku Sistem}

Mengidentifikasi pelaku sistem bertujuan untuk menemukan aktor yang berinteraksi dengan sistem, aktor dapat berbentuk seseorang atau pun sistem lain yang akan berinteraksi dengan sistem yang akan dirancang. Berikut hasil identifikasi pelaku sistem.

Tabel 7. Identifikasi Pelaku Sistem

\begin{tabular}{|c|c|l|}
\hline No & Nama Aktor & \multicolumn{1}{c|}{ Keterangan } \\
\hline 1 & $\begin{array}{c}\text { Admin } \\
\text { penjualan }\end{array}$ & $\begin{array}{l}\text { Aktor yang bertanggung jawab untuk mendata } \\
\text { penjualan barang, mencetak laporan penjualan } \\
\text { barang, dan cetak kwitansi. }\end{array}$ \\
\hline 2 & Admin gudang & $\begin{array}{l}\text { Aktor yang bertanggung jawab untuk mendata } \\
\text { barang yang masuk dan keluar gudang serta } \\
\text { memanajemen stok dan data barang, mencetak } \\
\text { laporan penerimaan barang, stok barang. }\end{array}$ \\
\hline 3 & Owner & $\begin{array}{l}\text { Aktor yang merupakan pemilik toko, } \\
\text { bertanggung jawab untuk mendata pembelian } \\
\text { barang kepada supplier. Owner dapat } \\
\text { mencetak data informasi laporan penjualan } \\
\text { barang, laporan penerimaan barang, dan } \\
\text { laporan stok barang. }\end{array}$ \\
\hline
\end{tabular}

\section{IV.7 Diagram Usecase}

Diagram use case dibutuhkan untuk menggambarkan aktivitas apa saja yang dapat dilakukan setiap aktor di dalam sistem. Berdasarkan data dari identifikasi perilaku sistem dan identifikasi use case, maka digambarkan dalam bentuk diagram use case berikut.

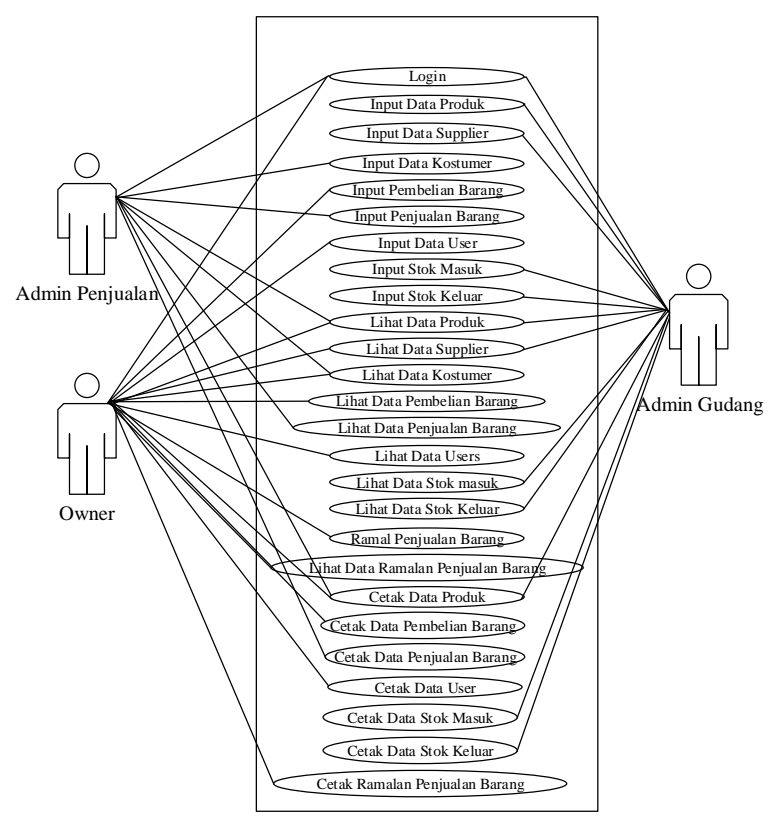

Gambar 6. Diagram Usecase

\section{KESIMPULAN DAN SARAN}

\section{V.1 Kesimpulan}

Kesimpulan dari penelitian ini adalah sebagai berikut.

1. Dari analisis kebutuhan, dapat diketahui 6 identifikasi masalah yang ada pada setiap stakeholder, 9 point kebutuhan fungsional, dan 15 point kebutuhan non fungsional.

2. Dari analisis data, dapat diketahui konstanta terbaik adalah $\alpha=0,5$ dengan kesalahan terkecil pada dua metode perhitungan ketepatan ramalan yaitu MAD $=15$ dan MAPE $=12,54 \%$, sehingga dapat diketahui ramalan bulan berikutnya adalah untuk ramalan penjualan bingkai ukuran A4 pada bulan agustus 2019 adalah 135 pcs.

3. Dari analisis proses bisnis didapatkan 4 flowchart yaitu, 3 flowchart bisnis yang sedang berjalan, dan 1 flowchart proses bisnis yang akan dikembangkan. 2 tabel identifikasi yaitu identifikasi pelaku sistem dan identifikasi usecase.

4. Dari hasil perancangan, didapatkan 5 hasil perancangan diagram UML yaitu diagram kontek, diagram usecase, diagram kelas, diagram sekuen, dan diagram aktivitas. 2 desain

Hari Irawan Azis, Nurul Kamilah, Dewi Primasari Jurnal Ilmiah Teknologi Informasi Terapan

Volume 7, No 1, 15 Desember 2020 
rancangan yaitu, rancangan database, dan rancangan tampilan.

\section{V.2 Saran}

"Sistem Peramalan Penjualan Barang Menggunakan Metode Forecasting Expoential Smoothing Di Waroeng Bingkai" saat ini masih meramalkan dalam periode perbulan, sehingga masih dapat dikembangkan lebih jauh lagi, yaitu dengan menambahkan fitur peramalan dalam periode pertahun dan dapat dikembangkan untuk menghitung total pendapatan dan perhitungan pajak yang harus dikeluarkan.

\section{REFERENSI}

Prawirosentono, S. (2005). Riset Operasi dan Ekonofisika. Jakarta: Bumi Aksara.

Nugroho, E. (2010). Sistem Informasi Manajemen: Konsep, Aplikasi, Dan Perkembangannya. Yogyakarta: Andi.

Sutabri, T. (2012). Analisis Sistem Informasi. Yogyakarta: Andi.

Heizer, J., \& Render, B. (2015). Manajemen Operasi: Manajemen Keberlangsungan dan Rantai Pasokan (Edisi 11). Hirson Kurnia, Jakarta: Salemba Empat.

Sommerville, I. (2007). Software Engineering. $8^{\text {th }}$ Edition. Scotland: Pearson Education Limited.

Hari Irawan Azis, Nurul Kamilah, Dewi Primasari

Jurnal Ilmiah Teknologi Informasi Terapan

Volume 7, No 1, 15 Desember 2020 